\title{
Digital Competence in Higher Education: Students' Perception and Personal Factors
}

\author{
Yu Zhao ${ }^{1, *(\mathbb{D})}$, María Cruz Sánchez Gómez ${ }^{2} \mathbb{D}$, Ana María Pinto Llorente ${ }^{2}$ and Liping Zhao ${ }^{3}$ \\ 1 Institute of Educational Sciences, University of Salamanca, 37008 Salamanca, Spain \\ 2 Department of Didactic, Organization and Research Methods, University of Salamanca, \\ 37008 Salamanca, Spain; mcsago@usal.es (M.C.S.G.); ampintoll@usal.es (A.M.P.L.) \\ 3 Faculty of Humanities, Gansu Agricultural University, Lanzhou 730070, China; zhaolp@gsau.edu.cn \\ * Correspondence: zhaoy426@yahoo.com
}

check for updates

Citation: Zhao, Y.; Sánchez Gómez, M.C.; Pinto Llorente, A.M.; Zhao, L. Digital Competence in Higher Education: Students' Perception and Personal Factors. Sustainability 2021, 13, 12184. https://doi.org/10.3390/ su132112184

Academic Editor: Barbara Motyl

Received: 5 October 2021

Accepted: 2 November 2021

Published: 4 November 2021

Publisher's Note: MDPI stays neutral with regard to jurisdictional claims in published maps and institutional affiliations.

Copyright: (c) 2021 by the authors. Licensee MDPI, Basel, Switzerland. This article is an open access article distributed under the terms and conditions of the Creative Commons Attribution (CC BY) license (https:/ / creativecommons.org/licenses/by/ $4.0 /)$.

\begin{abstract}
University students are expected to have the appropriate digital competence to face the demands of the changing educational model and to meet the challenges of the future work. This paper describes university students' perceptions of digital competence and analyzes the impact of personal factors on digital competence in a sample of 5164 students from all majors in the first and fourth year of their studies at Gansu Agricultural University (China). A quantitative methodology was followed, employing a non-experimental method and the survey technique to collect data. The results obtained show that students' perceptions of digital competencies in terms of information and data literacy, communication and collaboration, and safety were positive. Furthermore, there were significant differences in students' self-perceptions of digital competence related to gender, grade level, area of residence, and prior relevant training in the DigComp framework-based instrument. The development of key competency areas for digital competence, such as the creation of digital content, should be promoted, along with helping students to gain knowledge when dealing with everyday technological issues. The need for training related to the use of ICT and digital competencies was also highlighted, as well as supporting the promotion of female students in selected areas of digital competence and assisting lower grade students and students from rural areas in digital competence development.
\end{abstract}

Keywords: digital competence; students; higher education; ICT

\section{Introduction}

Over the past decade society has witnessed many social, economic and cultural changes. Technological developments have allowed information and communication technologies (ICT) to permeate all areas of human activity. The increasingly accelerated digitalisation process has led to an increased focus on and demand for digital related competencies. The new demanding skills for the development of future talents in society have led to new strategies.

Issues of digital competence have become more crucial after the novel coronavirus (COVID-19) outbreak was declared as a global pandemic by the World Health Organization (WHO) on 11 March 2020, since that time, school closures in response to COVID-19 have disrupted conventional schooling and educational activities have been transformed into an online model [1]. Indeed, the spreading of the epidemic has forced an acceleration in the integration of technology into the education field, meanwhile, new digital skills, knowledge and attitudes have determined the current shape of crisis e-learning. Events are exposed the weaknesses of education systems around the world today and have highlighted the impact of the digital divide on education. For the past year, the importance of digital competence at different educational levels has been clearly observed worldwide [2-4].

States and institutions have been responding to ensure the quality of education and to accelerate progress towards Sustainable Development Goals (SDGs), which have been 
presented by the United Nations and are aimed at achieving a better and more sustainable future for all. In order to support the sustainable and effective adaptation of education and training systems, the European Union released a digital education action plan (20212027) that focuses primarily on promoting the development of a high-performing digital education ecosystem and on improving digital skills and capabilities for digital transformation [5]. In alignment with the European Commission in fostering digitization in education, the 2025 Digital Spain has been presented. This includes guaranteeing adequate digital connectivity, bridging the digital divide in education and strengthening competencies in cybersecurity [6]. Moreover, the 48th China Statistical Report on Internet Development indicates that there are 325 million online education users in China and emphasizes the regulation of online education management [7]. Also the Cyberspace Administration of China published a Digital China Development Report, that takes the construction of Digital China as the overall strategy for the development of national informatization in the new era, through reducing the digital divide, developing the digital citizenship and enhancing the development of digital competence [8].

In addition to the new pedagogical challenges faced by teachers, the digital competence of students plays an important role in the new learning paradigm. As they are the main subjects of education, students should be prepared to use digital competence in their academic life and in their careers [9]. Digital competence is not only the basis for the use of digital technologies, but can also link to various required literacy for students. Students with higher digital competence can have better academic engagement and study enthusiasm, which are major concerns among world-wide universities and higher education institutions [10-12]. The development of digital competence needs to be perceived as part of lifelong learning [13].

\subsection{Digital Competence}

Digital competence has been frequently investigated and discussed by academic scholars and in policy documents, and it is also growing focus in higher education. Now that the teaching and learning environment has indeed changed, the use of ICT has penetrated into the study process and is closely linked to the academic performance of teachers and students alike [14].

There are several interpretations of the concept of digital competence, which is a broad concept [15]. Digital competence is defined as a set of required knowledge, skills and attitudes when using digital technologies to effectively optimize our everyday life [16]. It has been included in the recommendations on key competences for lifelong learning proposed by the European Commission as one of the eight key life skills, and it is defined as "the confident, critical and responsible use of, and engagement with, digital technologies for learning, at work, and for participation in society " [17] (p. 10). Digital competence is also understood as a cognitive, attitudinal and technological skill that helps to alleviate many of the problems and challenges in today's knowledge society and it has a dynamic and transversal character [18]. Digital competence involves not only digital skills, but also the social and emotional aspects of using and understanding digital devices and related technologies. Referring to the OECD project, "A competency is more than just knowledge and skills. It involves the ability to meet complex demands, by drawing on and mobilizing psychosocial resources (including skills and attitudes) in a particular context" [19] (p. 4). Digital competence is conceived as a multifaceted moving target, covering different areas and incorporating multiple fields. Moreover, Calvani generalized that digital competence is made up of both specific and non-quantifiable skills. In this context, the coexistence of dimensions at the technical, cognitive and ethical levels, and the integration of relevant skills within these dimensions, are highlighted [20,21].

In the context of education, digital competence is considered as the ability, along with a strong theoretical foundation, investigation and experimentation to apply the knowledge, attitudes and skills necessary to plan, implement, evaluate and continually review ICT-supported teaching and learning processes [22].The pedagogical community 
has realized the importance of digital competence for teaching and learning and considered it to be helpful in solving many problems in the teaching and learning process [23]. For educational organizations, the Joint Research Centre (JRC) published a Framework for Digitally Competent Educational Organizations (DigcompOrg), which helps to facilitate the process of systematically integrating digital learning in educational organizations from a pedagogical, technological and organizational perspective [24]. For teachers, digital competence is using ICT with a good pedagogical-didactic ICT understanding and being aware of how this might impact the learning strategies and educational formation of pupils [25]. A digital Competence Framework for Educators (DigcompEdu) was published in 2017, indicating the six competency areas that trainers need to develop [26]. The ministry of Education of China also released a project to enhance school teachers' ICT related abilities.

Digital competence is defined in a variety of ways and there is currently no single concept that is accepted and agreed upon by the general public. However, it is clear from the above-mentioned understandings and perceptions of experts and scholars that digital competence should be seen as an important survival skill and knowledge asset in the digital age, referring to the ability to learn, work, relax, play and use ICT confidently and creatively.

Today's students are growing up in a background of modern technology, and are recognized as digital natives [27]. Students with the ability to create and manage content and information, the control of communication tools, and the resolution of technological problems can make themselves more capable and competitive in order to meet the demands of today [28,29]. Moreover, influenced by the COVID-19 pandemic, innovation has driven teaching and learning, profoundly affecting learning models and teaching philosophies. Students, as the main participants in education, need to be equipped with digital competence to face the new challenges [30]. However, most students do not have the required digital competence level [31]. Technology is still not well blended into either classroom or online learning. Although some studies have shown that students perform positively in some areas of digital competence, there is still a long way to go before they are fully competent [32-34]. The fact that the students do not have sufficient digital competence is confirmed by all the difficulties and challenges that arose during the lock-downs.

It is also worth noting that the importance of digital competence and the incorporation of ICT tools into the educational process has been recognized by organizations, institutions and scholars. Several plans and blue papers aimed at accelerating the digitization and informatization process, with the purpose of strengthening digital competence, have been released [35,36]. There are studies focusing on investigating teachers' digital competence $[4,37,38]$. Other studies have investigated the factors influencing the development of digital competence, or the teaching methods involved in digital competence [39-42]. However, few studies have investigated the digital competence of Chinese university students, despite the fact that there are over 30 million undergraduate students in general higher education institutions in China [43].

\subsection{Digcomp}

In recent years, digital competence has been assessed and certified by different dimensions in the context of education from various perspectives [44]. A European Digital Competence Framework (Digcomp) is widely used to support strategic planning and policy-making, to develop education and training initiatives and to assess participants' digital competence [45]. Digital competence is defined as the use of ICT confidently, critically and creatively to achieve the goals related to work, employability, learning, leisure, social inclusion, and participation in society [46].

The European Commission first proposed Digcomp in 2013 as a road map on how to use and revise digital competence, and it identifies the key elements of digital competence, which address the knowledge, skills and attitudes required for digital competence. In 2016, Digcomp version 2.0 was launched in response to the new requirements brought about 
by the rapid development of digitization in all areas of society since the digital evolution has made itself re-written, which the competence areas, the competence descriptors and their titles have been updated. The report DigComp 2.0 presents 21 competencies with an updated list of five competency areas: (1) information and data literacy; (2) communication and collaboration; (3) digital content creation; (4) safety; and (5) problem solving. Digcomp 2.1 added eight proficiency levels and new examples of use. Moreover, from January 2021, the Digcomp 2.2 version is already being drafted and will be released in 2022. It focuses on the list of examples of knowledge, skills and attitudes applicable to each one of the 21 DigComp competences [13,45]. A comparison of DigComp 1.0, DigComp 2.0 and DigComp 2.1 is presented in Table 1 .

Table 1. The comparison of Digcomp 1.0; Digcomp 2.0 and Digcomp 2.1.

\begin{tabular}{|c|c|c|c|c|}
\hline \multicolumn{2}{|c|}{ Digcomp 1.0} & \multicolumn{2}{|c|}{ Digcomp 2.0} & \multirow[t]{2}{*}{ Digcomp 2.1} \\
\hline Information & $\begin{array}{l}\text { 1.1. Browsing, searching and } \\
\text { filtering information } \\
\text { 1.2. Evaluating Information } \\
\text { 1.3. Storing and retrieving } \\
\text { information }\end{array}$ & $\begin{array}{l}\text { Information and data } \\
\text { literacy }\end{array}$ & $\begin{array}{l}\text { 1.1. Browsing, searching } \\
\text { and filtering data, } \\
\text { information and digital } \\
\text { content } \\
\text { 1.2. Evaluating data, } \\
\text { information and digital } \\
\text { content } \\
\text { 1.3. Managing data, } \\
\text { information and digital } \\
\text { content }\end{array}$ & \\
\hline Communication & $\begin{array}{l}\text { 2.1. Interacting through } \\
\text { technologies } \\
\text { 2.2. Sharing information and } \\
\text { content } \\
\text { 2.3. Engaging in online } \\
\text { citizenship } \\
\text { 2.4. Collaborating through } \\
\text { digital channels } \\
\text { 2.5. Netiquette } \\
\text { 2.6. Managing digital identity }\end{array}$ & $\begin{array}{l}\text { Communication and } \\
\text { collaboration }\end{array}$ & $\begin{array}{l}\text { 2.1. Interacting through } \\
\text { digital technologies } \\
\text { 2.2. Sharing through } \\
\text { digital technologies } \\
\text { 2.3. Engaging in } \\
\text { citizenship through digital } \\
\text { technologies } \\
\text { 2.4. Collaborating through } \\
\text { digital technologies } \\
\text { 2.5. Netiquette } \\
\text { 2.6. Managing digital } \\
\text { identity }\end{array}$ & \multirow{4}{*}{$\begin{array}{l}\text { Based on the dimensions } \\
\text { from Digcomp 2.0, eight } \\
\text { proficiency levels for each } \\
\text { of the } 21 \text { competences } \\
\text { and examples of use of the } \\
\text { eight proficiency levels } \\
\text { applied to learning and } \\
\text { employment scenario in } \\
\text { the } 21 \text { competences have } \\
\text { been added and updated. }\end{array}$} \\
\hline Content creation & $\begin{array}{l}\text { 3.1. Developing content } \\
\text { 3.2. Integrating and } \\
\text { re-elaborating } \\
\text { 3.3. Copyright and Licences } \\
\text { 3.4. Programming }\end{array}$ & Digital content creation & $\begin{array}{l}\text { 3.1. Developing digital } \\
\text { content } \\
\text { 3.2. Integrating and } \\
\text { re-elaborating digital } \\
\text { content } \\
\text { 3.3. Copyright and } \\
\text { licences } \\
\text { 3.4. Programming }\end{array}$ & \\
\hline Safety & $\begin{array}{l}\text { 4.1. Protecting devices } \\
\text { 4.2. Protecting personal data } \\
\text { 4.3. Protecting health } \\
\text { 4.4. Protecting the } \\
\text { environment }\end{array}$ & Safety & $\begin{array}{l}\text { 4.1. Protecting devices } \\
\text { 4.2. Protecting personal } \\
\text { data and privacy } \\
\text { 4.3. Protecting health and } \\
\text { well-being } \\
\text { 4.4. Protecting the } \\
\text { environment }\end{array}$ & \\
\hline Problem Solving & $\begin{array}{l}\text { 5.1. Solving technical } \\
\text { problems } \\
\text { 5.2. Identifying needs and } \\
\text { technological responses } \\
\text { 5.3. Innovating and creatively } \\
\text { using technology } \\
\text { 5.4. Identifying digital } \\
\text { competence gaps }\end{array}$ & Problem Solving & $\begin{array}{l}\text { 5.1. Solving technical } \\
\text { problems } \\
\text { 5.2. Identifying needs and } \\
\text { technological responses } \\
\text { 5.3. Creatively using } \\
\text { digital technologies } \\
\text { 5.4. Identifying digital } \\
\text { competence gaps }\end{array}$ & \\
\hline
\end{tabular}

The five areas of digital competencies and the 21 subdivided competencies identified in the DigComp conceptual reference model provide a strong common understanding of the digital competencies demanded by today's society [47]. 
Within each of the digital competency areas, a range of skills are included that are often associated with it. Of these specific competencies, professional knowledge, skills, attitudes, technical and operational competencies including operating processes are the main components [48]. Furthermore, there is a large amount of overlap and cross-reference between areas and competencies. It is also important to emphasize that the DigComp framework is not prescriptive, but rather descriptive, and that this descriptive nature can help to adapt to the specific needs of the target group.

On the basis of the preceding literature review, it is argued that the digital competence of students is crucial to society. Moreover, understanding their digital competence can provide information, recommendations and support for the future development of education in a digital environment. Digital competence has been recognized as a key competence in different European frameworks and has a solid theoretical foundation. China is now in a critical process of digitization, but compared to the well-established digital competence frameworks in European countries, a framework for assessing Asian students' digital competence in line with Eastern education systems has not yet been released. Digital competence is one of the challenges facing both the EU and China, so the development of communication, frameworks, platforms, methods and validation schemes could be instructive for both sides as well as for education [49]. In this paper we bring the European digital competence framework into the context of the Eastern education system and use the Digcomp-based instrument to explore the digital competence of Chinese students. Also, as university students are not only under pressure to study, but also to enter society, face the challenges of the workplace and exercise their digital citizenship rights, it is vital to understand their digital competences.

Therefore, in this paper, we concentrate on students' digital competence in higher education, with the goals of describing university students' perception of their digital competence and exploring whether there are significant differences based on established variables such as gender, grade, residential areas and previous formal training in ICT use and digital competence.

Based on this, the research questions are:

1. What are university students' perception of their digital competence?

2. Whether there are significant differences based on established variables (gender, grade level, residential areas and previous formal training in the use of ICT and digital competence)?

\section{Materials and Methods}

To carry out this study, a quantitative methodology with survey-based was employed. We used a non- experimental design for this study that there is no treatment of any variables for modification or application, but only selection, observation and collection of information needed to solve the research questions. In order to reach the study's objectives, we also performed a descriptive, inferential data analysis [50].

\subsection{Sample}

The population that constituted the study sample was composed of students from all faculties who were freshmen and fourth-year students at Gansu Agricultural University in China in the 2019/2020 academic year. We used random sampling techniques. The random, representative sample consisted of 5164 subjects (estimation error $\mathrm{E}=1.36$, $\alpha=(100-95) / 100=0.05)$.

In total, there were $3136(60.7 \%)$ first year students and 2028 (39.3\%) students in their fourth year. The average age was 20.15 and ranged from 15 to 30 years old. And in the sample, $56.9 \%(n=2940)$ of the students were women and $43.1 \%(2240)$ were men. Most of them lived in rural areas $(70.5 \%, n=3634)$.

$50.5 \%$ of the subjects had received formal training in the use of ICT and digital competence. The majority of them had participated in online class $(75.3 \%)$. In order to improve students' digital competence, $59.1 \%$ of the subjects chose to attend school courses. 


\subsection{Instrument}

The instrument used for this study was a questionnaire adapted from a diagnostic questionnaire for university students presented by Martínez Vidal y Cervera [51] and the Ikanos self-assessment tool from the Ikanos project.

In 2012, The Basque Government (Spain) launched the Ikanos project to meet both common and specific digital competence needs. It has been developed and expanded several times promoting the Information and Knowledge Society and motivating the acquisition of digital competence $[45,52]$. Inspired by Digcomp, Ikanos was designed to satisfy the digital competence requirements of different segments and aspects of society. The Ikanos self-assessment tool can help to provide a personal digital profile, indicating the level of digital competence according to the five competency areas of the DigComp model.

We wrote a draft that included all items deemed necessary to meet the study objectives. The validation of the instrument was reviewed by a panel of experts who analyzed the content validity and an exploratory factor analysis was applied to complete the construct validity. The questionnaire was initially written in Spanish and translated into Chinese, considering the participants' mother tongue. The characteristics and external validity of the questionnaire were examined in discussion with experts in the fields of research methods, education and linguistics. The questionnaire was then revised in line with the recommendations of the experts. The reliability of the instrument was measured. The Cronbach's Alpha coefficient reached a value of 0.978 , representing a very high level of reliability [53].

The questionnaire has 70 items and it is divided into six sections (Table 2).

Table 2. Sections of the questionnaire.

\begin{tabular}{cc}
\hline Identification & Age; gender; grade; residential zone; major and reason for choosing a major. \\
\hline Availability of ICT resources & $\begin{array}{c}\text { Device connection to the Internet; campus networking and owned equipment } \\
\text { and device }\end{array}$ \\
\hline $\begin{array}{c}\text { Potential for digital competence development } \\
\text { ICT and digital related training }\end{array}$ & $\begin{array}{c}\text { Frequency of connecting to the Internet; connection with the Internet and the } \\
\text { purpose of using the ICT tools. }\end{array}$ \\
$\begin{array}{c}\text { Previous training on the use of ICT and digital competence reception; } \\
\text { appoaches to improving digital competence; online classes participation and } \\
\text { level of computer usage. }\end{array}$ \\
\hline Self-perception in digital competence & $\begin{array}{c}\text { Information and data literacy; communication and collaboration; digital } \\
\text { content creation; safety and problem solving. }\end{array}$ \\
\hline Attitude & Attitude towards ICTs.
\end{tabular}

The items are made up of closed-ended, multiple choice and 4-interval Likert-type ordinal scale questions, with the intention to avoid deviations. Participants should respond to all questions according to their real situation.

\subsection{Data Collection and Analysis Procedures}

Data collection was carried out in the academic year 2019-2020 in the subject in China. The questionnaire was completed digitally through the Qualtrics platform and was distributed to the first and fourth year students by sharing the OR code created by Qualtrics. And the questionnaire was anonymous. Before answering the questionnaire, supervising teachers explained the purpose of the study and asked for the cooperation of the students.

The data obtained were analyzed with the Statistical Package for the Social Sciences (v.26). A confidence level of $95 \%$ was used in all analyses. Descriptive statistical analysis was carried out on all responses, with the mean and standard deviation calculated. In order to have a better understanding of the personal variables that determine the digital competence of university students, several inferential statistical analyses were performed. 
Analyses were carried out, to determine whether there were significant differences in their perception of digital competence due to gender, grade, residential area and previous training. According to the Kolmogorov-Smirnov test, there was no normality in the distributions ( $p$-value is 0.000). And the non-parametric Mann-Whitney $\mathrm{U}$ test was employed for the dual variable.

\section{Results}

As there is a large amount of data available throughout the entire study, this paper will only focus on the fifth part of the data: students' self-perceptions of digital competence.

\subsection{Descriptive Analysis}

University students' perception of their digital competence ( 39 items) will be presented according to the following competency areas: information and data literacy (6 items); communication and collaboration (13 items); digital content creation (6 items); safety ( 7 items) and problem solving ( 7 items). As mentioned above, to avoid bias, participants responded on a Likert-type scale of 1 to 4 .

Table 3 shows basic descriptive statistical results of students' self-perceptions of digital competence in terms of information and data literacy.

Table 3. University students' self-perception of digital competence in information and data literacy.

\begin{tabular}{|c|c|c|c|c|c|c|}
\hline Information and Data Literacy & Very Poor & Poor & Good & Very Good & Mean & SD \\
\hline $\begin{array}{l}\text { I use ICT tools to search, locate, select, organize, } \\
\text { evaluate, process, store, transform, disseminate, cite } \\
\text { and communicate information. }\end{array}$ & 6.9 & 20.5 & 62.6 & 10.1 & 2.76 & 0.722 \\
\hline $\begin{array}{l}\text { I use specialized search engines and meta-search } \\
\text { engines with various mechanisms (Identify keywords, } \\
\text { synonyms and related terms, search in more than one } \\
\text { language...). }\end{array}$ & 3.8 & 14.5 & 63.9 & 17.8 & 2.96 & 0.687 \\
\hline $\begin{array}{l}\text { I understand different sources of information and can } \\
\text { build search strategies correctly based on them. }\end{array}$ & 6.2 & 27.3 & 55.7 & 10.7 & 2.71 & 0.738 \\
\hline $\begin{array}{l}\text { I analyse and comment critically on information, data } \\
\text { sources and digital content, verify the validity and } \\
\text { timeliness of the information located. }\end{array}$ & 7.0 & 29.3 & 54.3 & 9.4 & 2.66 & 0.743 \\
\hline $\begin{array}{l}\text { I apply different methods and tools to manage and } \\
\text { store information, data and digital content for easy } \\
\text { retrieval. }\end{array}$ & 6.5 & 28.0 & 55.5 & 10.1 & 2.69 & 0.738 \\
\hline $\begin{array}{c}\text { I have my own strategy to organize and retrieve } \\
\text { information and data. }\end{array}$ & 7.4 & 27.2 & 54.8 & 10.5 & 2.68 & 0.758 \\
\hline
\end{tabular}

The majority of students perceived themselves good in browsing, searching and filtering data, information and digital content. And there were $54.3 \%$ students who believed that they were good in the evaluation of information, data and digital content. When students were asked about managing data, $55.5 \%$ claimed they were good. In regard to information organization and retrieval of data, $54.8 \%$ thought that had reached a good level (Table 3).

The results obtained refer to communication and collaboration (Table 4) and indicate that the university students are good at using digital devices and applications to communicate with others $(\mathrm{M}=3.00, \mathrm{SD}=0.661) .59 .7 \%$ of the students chose good when asked about digital participation. While $56.3 \%$ perceived themselves good in terms of collaborating with others through the Internet and in forming their PLN. As for the students citizenship engagement through digital technologies, the majority of them $(61.2 \%)$ thought they were good. In relation to the collaboration through digital technologies, more than half of the students indicated themselves as good in using digital technologies and media 
for teamwork $(61.7 \%)$, to process their activities and projects $(56.4 \%)$ and participating in online learning activities through collaborative environments (56.9\%). Most of the students were well aware of behavioral norms and knowledge when using digital technology and interacting in a digital environment $(\mathrm{M}=3.05, \mathrm{SD}=0.687 ; \mathrm{M}=3.06, \mathrm{SD}=0.660 ; \mathrm{M}=3.03$, $\mathrm{SD}=0.656)$. Similar results were observed in terms of students managing their digital identity: $60.5 \%$ knew well how to create and manage their profile on social media, $58.8 \%$ could manage several identities in different contexts and $63.1 \%$ indicated their good ability in controlling and protecting digital reputation.

Table 4. University students' self-perception of digital competence in communication and collaboration.

\begin{tabular}{|c|c|c|c|c|c|c|}
\hline Communication and Collaboration & Very Poor & Poor & Good & Very Good & Mean & SD \\
\hline $\begin{array}{c}\text { I communicate and interact through a variety of digital } \\
\text { devices and applications (SMS, email, cloud, QQ, } \\
\text { WeChat, video conferencing). }\end{array}$ & 3.2 & 12.2 & 66.0 & 18.6 & 3.00 & 0.661 \\
\hline $\begin{array}{l}\text { I participate in social networks, collaborative platforms } \\
\text { and online communities where I share knowledge, } \\
\text { multimedia content and information. }\end{array}$ & 5.0 & 22.5 & 59.7 & 12.8 & 2.80 & 0.718 \\
\hline $\begin{array}{l}\text { I collaborate through the Internet with other people in } \\
\text { my educational or professional field that form my } \\
\text { personal learning network (PLN). }\end{array}$ & 6.6 & 26.7 & 56.3 & 10.4 & 2.71 & 0.740 \\
\hline $\begin{array}{c}\text { I engage with society through online participation } \\
\text { (social, political, cultural, administrative action) and am } \\
\text { aware of the potential of technology for citizen } \\
\text { participation. }\end{array}$ & 4.8 & 22.8 & 61.2 & 11.2 & 2.79 & 0.698 \\
\hline I use digital technologies and media for teamwork. & 4.6 & 22.4 & 61.7 & 11.3 & 2.80 & 0.692 \\
\hline $\begin{array}{l}\text { I use technology and collaboration tools to plan, execute } \\
\text { and share monitoring of activities and projects. }\end{array}$ & 6.0 & 27.4 & 56.4 & 10.2 & 2.71 & 0.728 \\
\hline $\begin{array}{l}\text { I participate in learning activities such as MOOCs } \\
\text { through collaborative environments. }\end{array}$ & 6.2 & 26.4 & 56.9 & 10.5 & 2.72 & 0.734 \\
\hline $\begin{array}{l}\text { I am familiar with the rules of conduct online or in the } \\
\text { virtual world, such as being friendly, respecting people's } \\
\text { privacy and being careful with my language. }\end{array}$ & 3.0 & 12.1 & 61.6 & 23.3 & 3.05 & 0.687 \\
\hline I stay up to date with ethics regarding internet use. & 2.7 & 10.7 & 64.4 & 22.1 & 3.06 & 0.660 \\
\hline $\begin{array}{l}\text { I take care to remind my family and friends of the basic } \\
\text { rules of behaviour on the Internet. }\end{array}$ & 2.6 & 12.3 & 64.5 & 20.6 & 3.03 & 0.656 \\
\hline $\begin{array}{l}\text { I know how to create and manage a public, personal and } \\
\text { professional profile on social media. }\end{array}$ & 4.5 & 19.6 & 60.5 & 15.4 & 2.87 & 0.716 \\
\hline $\begin{array}{l}\text { I am able to manage several digital identities depending } \\
\text { on the objective or context. }\end{array}$ & 5.2 & 22.2 & 58.8 & 13.8 & 2.81 & 0.730 \\
\hline $\begin{array}{l}\text { I pay attention to what I post online and I know how to } \\
\text { protect my digital reputation and/or that of others. }\end{array}$ & 2.6 & 10.2 & 63.1 & 24.0 & 3.09 & 0.661 \\
\hline
\end{tabular}

Table 5 shows the data referring to digital content creation. It is observed that only $49.1 \%$ students perceived themselves as good in using different tools and software to create multimedia content in various formats, $36.6 \%$ indicating themselves as poor. When using different media and methods to present their idea creatively, 50.6\% chose good and $35.6 \%$ thought that they were poor at it. Regarding the creation of new creative and relevant content by editing, modifying, improving and combining existing resources, $51.5 \%$ evaluated themselves as good. The results were similar in terms of understanding the basics of intellectual property, the law, and the licensing of information and digital content, with half of the students rating themselves as good (52.8\%). However, in the programming section, less than half of the students thought they had a good level (45.2\%) and only $43.7 \%$ 
indicated that they could make well modifications to computer programs, applications, configurations and equipment as needed.

Table 5. University students' self-perception of digital competence in digital content creation.

\begin{tabular}{|c|c|c|c|c|c|c|}
\hline Digital Content Creation & Very Poor & Poor & Good & Very Good & Mean & SD \\
\hline $\begin{array}{l}\text { I use a variety of tools and software to create multimedia } \\
\text { content in a variety of formats. }\end{array}$ & 7.7 & 36.6 & 49.1 & 6.7 & 2.55 & 0.732 \\
\hline $\begin{array}{l}\text { I am able to use different media and methods to present } \\
\text { ideas in a creative way. }\end{array}$ & 6.8 & 35.6 & 50.6 & 7.0 & 2.58 & 0.721 \\
\hline $\begin{array}{l}\text { I am able to edit, modify, improve and combine existing } \\
\text { resources to create new and relevant content and } \\
\text { knowledge. }\end{array}$ & 7.0 & 34.6 & 51.5 & 6.9 & 2.58 & 0.722 \\
\hline $\begin{array}{l}\text { I understand the basic knowledge and laws of } \\
\text { intellectual property and the licensing of information } \\
\text { and digital content when working with ICTs. }\end{array}$ & 6.5 & 32.6 & 52.8 & 8.2 & 2.63 & 0.726 \\
\hline $\begin{array}{l}\text { I know the basics of digital processes, understand the } \\
\text { principles of programming and what is behind a } \\
\text { programme. }\end{array}$ & 9.4 & 38.5 & 45.2 & 6.9 & 2.50 & 0.759 \\
\hline $\begin{array}{l}\text { I make modifications to computer programs, } \\
\text { applications, configurations and equipment as needed }\end{array}$ & 11.7 & 37.9 & 43.7 & 6.7 & 2.45 & 0.784 \\
\hline
\end{tabular}

The results of students' perception in terms of safety are showed in Table 6. The students mostly agreed that they were good in understanding the risks associated with the use of online tools and devices $(63.3 \%)$, and they reported they could protect their devices and content well $(61.1 \%)$. With regard to protecting their own the personal data and privacy, the majority of the students pointed out their good level on it $(\mathrm{M}=2.90$, $\mathrm{SD}=0.672$ ). Regarding the health and well-being protection, most students considered themselves good in terms of being aware of the associated risks and threats (64.5\%), protecting their health and well being when using the Internet and related technologies $(64.8 \%)$ and being knowledgeable about the influence of the use of technology on the environment $(65.5 \%)$. And $64.4 \%$ stated they could apply measures to save energy, recycle devices and contribute to environment protection.

Table 6. University students' self-perception of digital competence in safety.

\begin{tabular}{|c|c|c|c|c|c|c|}
\hline Safety & Very Poor & Poor & Good & Very Good & Mean & SD \\
\hline $\begin{array}{l}\text { I understand the risks associated with the use of online } \\
\text { tools and devices }\end{array}$ & 4.7 & 19.8 & 63.3 & 12.2 & 2.83 & 0.691 \\
\hline I protect my equipment and multimedia content & 4.3 & 22.5 & 61.1 & 12.1 & 2.81 & 0.695 \\
\hline I keep data security and protect my personal privacy. & 3.5 & 17.2 & 64.5 & 14.7 & 2.90 & 0.672 \\
\hline $\begin{array}{l}\text { I understand the health risks associated with the use of } \\
\text { related technologies. }\end{array}$ & 3.1 & 16.1 & 64.5 & 16.4 & 2.94 & 0.666 \\
\hline $\begin{array}{l}\text { I prevent and avoid physical and mental health threats } \\
\text { when using the Internet and multimedia devices, such as } \\
\text { poor sitting posture and cyberbullying. }\end{array}$ & 3.3 & 15.0 & 64.8 & 16.9 & 2.95 & 0.669 \\
\hline $\begin{array}{l}\text { I know the positive and negative aspects associated with } \\
\text { the use of technology on the environment. }\end{array}$ & 3.1 & 15.3 & 65.5 & 16.1 & 2.95 & 0.659 \\
\hline $\begin{array}{c}\text { I apply basic measures to save energy, recycle devices } \\
\text { and protect the environment. }\end{array}$ & 3.5 & 17.0 & 64.4 & 15.0 & 2.91 & 0.674 \\
\hline
\end{tabular}

Data referring to the students' perception of digital competence in problem solving (Table 7) shows that less than half of the students were well versed in operating digital 
equipment and identifying possible technical problems (48.7\%), and 35.1\% thought that they were bad at it. But when the real daily technical problem occurred, 52.3\% selected good, indicating that they could solve these problems well. In terms of identifying needs and technical responses, there were $58.6 \%$ of the students rated themselves as good. When students were asked about keeping up to date with new technological developments, trends and using digital technology to innovate, only $48.5 \%$ considered themselves as good, while $35.9 \%$ indicated that they were poor at it. Then in creatively using digital technologies, $56.2 \%$ of the students confirmed that they were at a good level. Similarly, $52.1 \%$ chose good with regard to participation in events and workshops on digital creation and collaborative multimedia and digital projects. In regards to identifying gaps in digital competence, $59.2 \%$ reported that they were aware of the need to improve and update their own digital competence and to help others develop theirs.

Table 7. University students' self-perception of digital competence in problem solving.

\begin{tabular}{|c|c|c|c|c|c|c|}
\hline Problem Solving & Very Poor & Poor & Good & Very Good & Mean & SD \\
\hline $\begin{array}{l}\text { I am familiar with the operation of digital devices and } \\
\text { am able to identify possible technical problems. }\end{array}$ & 8.1 & 35.1 & 48.7 & 8.2 & 2.57 & 0.755 \\
\hline I solve daily technical problems. & 6.6 & 33.0 & 52.3 & 8.1 & 2.62 & 0.728 \\
\hline $\begin{array}{l}\text { I evaluate and select appropriately a tool, device service } \\
\text { to perform my tasks and meet my needs. }\end{array}$ & 5.3 & 27.5 & 58.6 & 8.7 & 2.71 & 0.698 \\
\hline $\begin{array}{l}\text { I keep myself updated on new developments and } \\
\text { emerging technology trends, and innovate using digital } \\
\text { technology. }\end{array}$ & 7.7 & 35.9 & 48.5 & 7.9 & 2.57 & 0.747 \\
\hline $\begin{array}{l}\text { I use various methods such as text, images and audio to } \\
\text { make my expression more creative and innovative. }\end{array}$ & 5.3 & 29.6 & 56.2 & 8.8 & 2.69 & 0.706 \\
\hline $\begin{array}{l}\text { I actively attend events and workshops on digital } \\
\text { creation, and participate in collaborative multimedia and } \\
\text { digital projects. }\end{array}$ & 7.4 & 32.9 & 52.1 & 7.7 & 2.60 & 0.736 \\
\hline $\begin{array}{l}\text { I understand the needs to improve and update one's } \\
\text { own competence and to help others in developing their } \\
\text { digital competence. }\end{array}$ & 4.8 & 24.7 & 59.2 & 11.3 & 2.77 & 0.706 \\
\hline
\end{tabular}

\subsection{Inferential Analysis}

To conduct the inferential analysis, the Mann-Whitney test was applied. This section will present the factors that influence university students' perceptions of digital competence (gender, grade, residential area, previous formal training).

\subsubsection{Gender}

The Mann-Whitney $U$ test was used to determine whether there were differences between male and female students in terms of the various dimensions of digital competence. Statistically significant differences were found in terms of gender in the areas of information and data literacy, digital content creation and problem solving (MW $p$-value $=0.000$ ). The comparison of students' perceptions of digital competence between genders can be seen in Figure 1. Men (Median = 3.00) perceived that their digital competence level in information and data literacy section was significantly higher than that of women $($ Median $=2.83 ; \mathrm{MW} p$-value $=0.000)$. Women $($ Median $=2.50)$ rated themselves lower in digital content creation than men (Median $=2.67 ; \mathrm{MW} p$-value $=0.000$ ). Similar results were found in problem solving, in which men (Median $=3.00$ ) stated themselves better than women (Median $=2.71$ ). However, there was no significant difference between genders and the $p$ value was on the borderline of significance (MW $p$-value $=0.053$ ) in the communication and collaboration section. With regard to the safety section, the results showed no statistically significant difference between the scores of the male and female groups $(\mathrm{MW} p$-value $=0.709)$. 


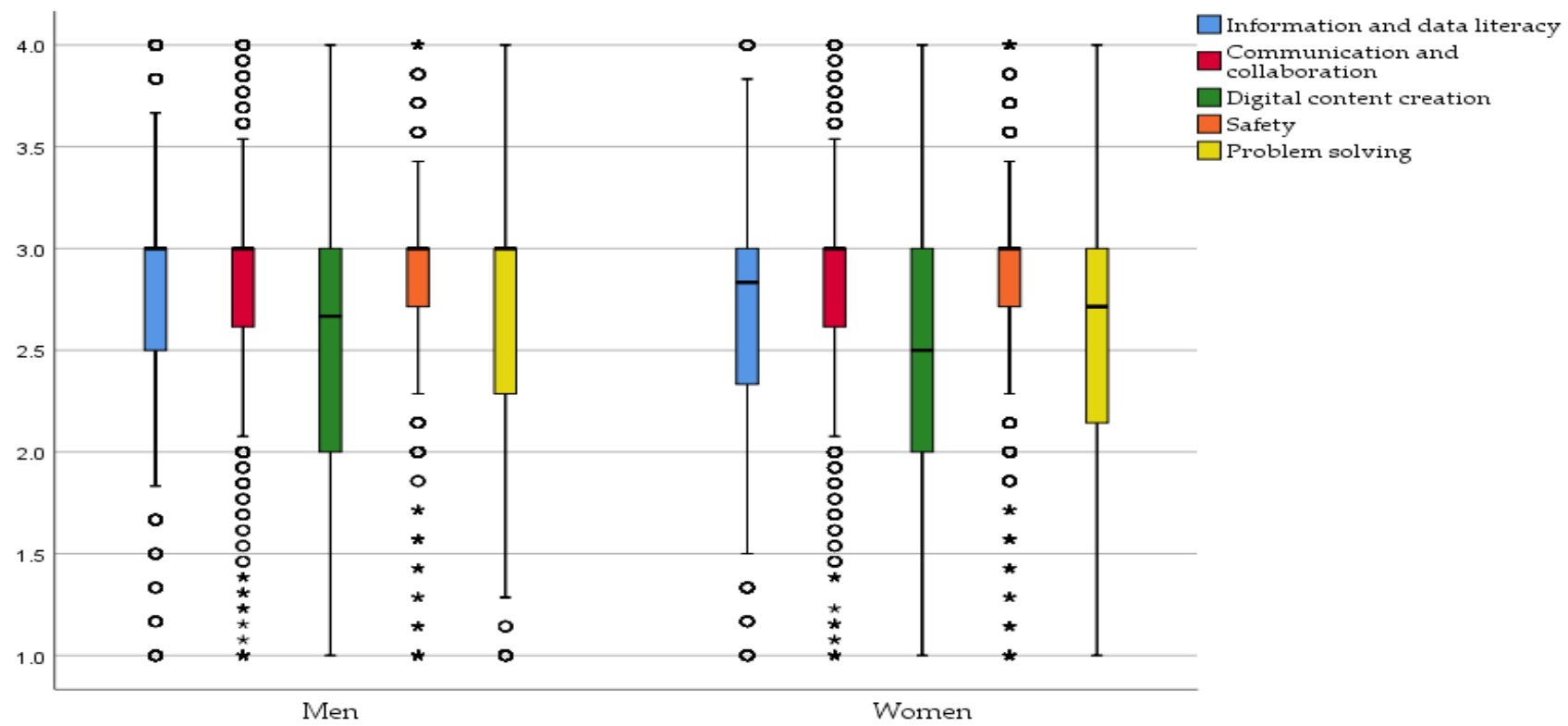

Figure 1. University students' self-perception of digital competence, by gender group.

\subsubsection{Grade}

Figure 2 illustrates the perceptions of different grades of university students about their digital competence. It is observed that the fourth year students (Median $=3.00$ ) perceived themselves as more capable than the first year students (Median = 2.83; MW $p$-value $=0.000$ ). The result of the Mann-Whitney test showed that there was a significant difference between first-year and fourth-year students' self-perceptions of their digital competence in the section of information and data literacy ( $\mathrm{MW} p$-value $=0.000$ ). In the digital content creation, the fourth year students (Median $=2.67$ ) stated a higher competence level than the first year students (Median $=2.5$; MW $p$-value $=0.000$ ). A similar result was seen in the problem solving section (MW $p$-value $=0.000)$. However, no statistical differences in digital competence safety dimension were found between students in different grades, since the $p$ value was 0.221 .

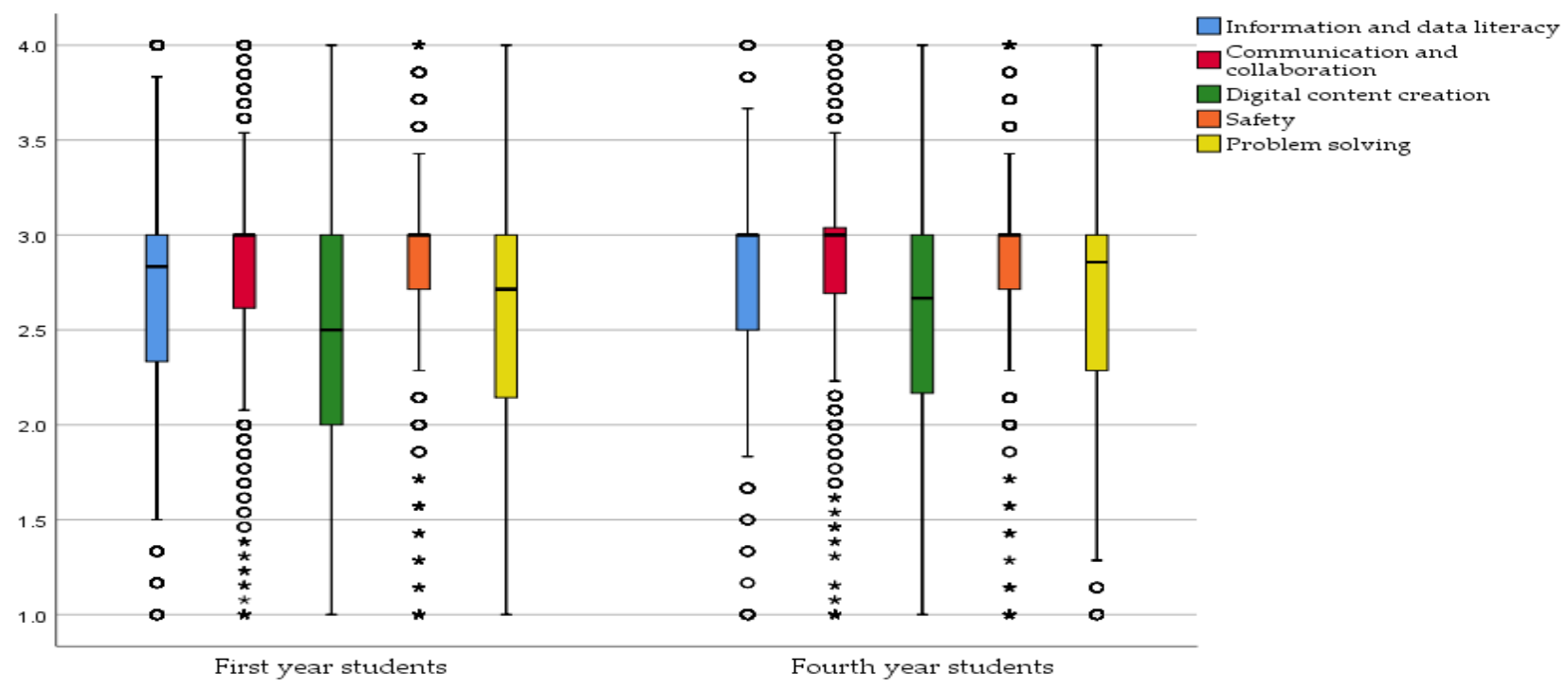

Figure 2. University students' self-perception of digital competence, by different grades. 


\subsubsection{Residential Area}

After applying the Mann-Whitney test, the results showed that there were significant differences in five areas of self-perceptions of digital competence between students coming from different residential areas (MW $p$-value $=0.000$ ). Students with an urban residence stated themselves better than students with a rural residence in the section of information and data literacy, communication and collaboration, digital content creation, as well as safety and problem solving ( Figure 3).

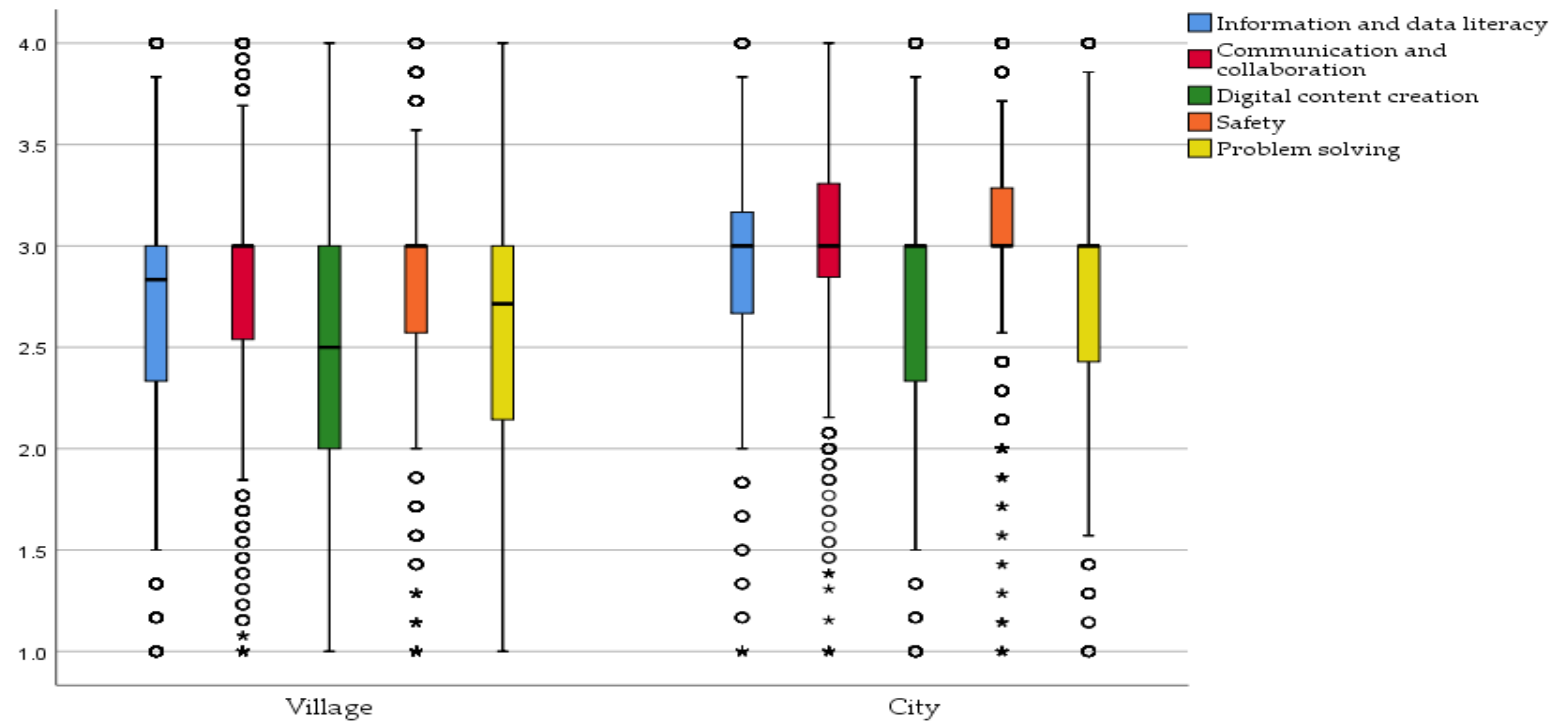

Figure 3. University students' self-perception of digital competence, by different residential areas.

\subsubsection{Previous Formal Training on the Use of ICT and Digital Competence}

According to the results obtained, with or without prior relevant formal training, students showed significant differences in all five areas of digital competence (MW $p$ value $=0.000$ ). Regarding the area of information and data literacy, students with previous training (Median $=3.00$ ) had a higher perception than those who had not received training (Median $=2.83$ ). In the areas of communication and collaboration, digital content creation, and safety and problem solving, we found similar results (Figure 4).

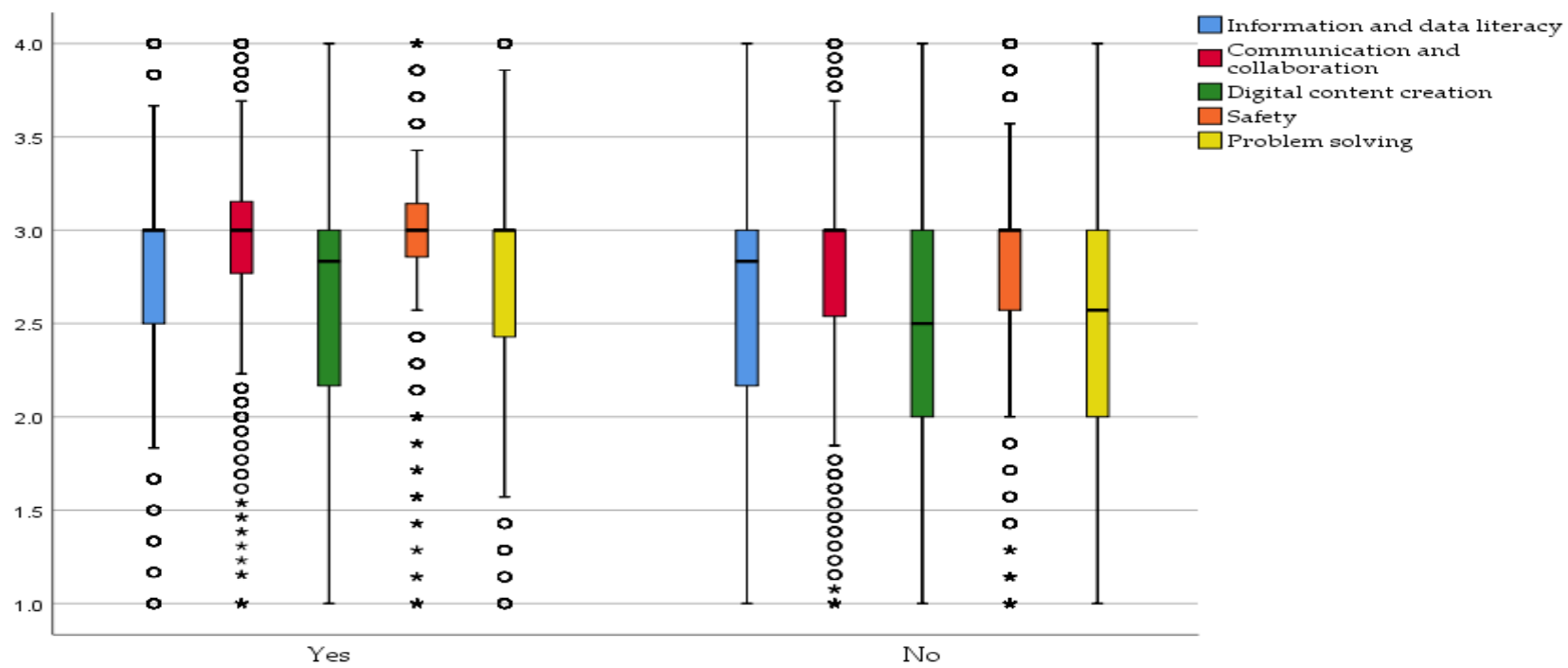

Figure 4. University students' self-perception of digital competence, by previous formal training. 


\section{Discussion}

A shift in the educational paradigm due to the accelerating digitalization process and the impact of the COVID-19 epidemic, as well as the goals of sustainable development, make it even more certain that digital competence is a core part of students' ability to achieve an adequate professional and academic performance, to meet society's requirements and to face future challenges [34,54].

Various studies have investigated the acquisition of digital competence, teachers' digital competence perception, and examined the relationship between different dimensions $[4,55,56]$. This paper explores students' perceptions of their level of digital competence in the context of higher education, based on a case study of students at Gansu Agricultural University in Northwest China. Generally speaking, most students perceived their level of digital competence as positive. It was also observed that students demonstrated digital competence in several areas such as information and data literacy, communication and collaboration. We agree with [57] and [58], whose findings on university students' digital competence have led to identify that students' perception of digital competence decreased when the complexity of tasks increased. Therefore, many students need to improve their level of competence when creating digital content and programming, as well as parts of their problem-solving skills when facing technical problems and the understanding of technological trends. The results obtained were similar to the research done by $[59,60]$. Furthermore, students showed their positive perceptions in the safety section of digital competence, which showed contrary results to those obtained by [61]. Overall, the level of digital competence of university students still has potential for further development.

In the current scientific research, gender is one of the most widespread variables [62]. There are several studies that have examined the impact of gender on digital competence, indicating significant differences [63-65]. At the same time, there are some research studies that have obtained a contrary result that no significant differences were found regarding gender [66-70]. In this study we have verified that university men students rating themselves higher than university women students in several sections of digital competencies such as information and data literacy, digital content creation and problem solving. We therefore agree with $[58,71,72]$ whose work indicated that men have showed a better digital competence than women. However, there are also studies showing the opposite findings against the gender stereotypes associated with digital competence [73].

As opposed to many authors who have explored age gaps in digital competence issues, only a few studies point to gaps in digital competence between different grades [74]. So, due to the small age range of the university students who were the subject of this paper, we examined the differences in perceptions of digital competence between first year and fourth year students. It has been demonstrated that students in the higher grades have showed better self-perception in all areas of digital competence, based on the Digcomp framework. As the results are similar to those reported in terms of age differences, it remains to be further investigated whether the reason for this variation is due to their age or their school training strategy.

Regarding the variable of residential area, firstly, there is still a digital divide between rural and urban areas, resulting from demographic variables such as the age and education level of the population and the connection to the international internet $[75,76]$. The results in this study are consistent with [77], showing that digital competence is perceived to be on average better in university students living in urban areas.

In relation to the students' previous formal training on the use of ICT and digital competence, it has been indicated that half of the university students have already received prior formal relevant training. Training in digital competence and the use of ICT does not fully cover upper secondary education prior to entering university, and the design of relevant university curricula has not spread to all majors. In agreement with [3], there is a relationship between training and students' subsequent development of digital competence. The impact of previous formal training has been confirmed by the results that students with previous formal training show a higher level of self-perception in terms of digital 
competence. Similar results were obtained and mentioned by $[78,79]$ as well. Many studies have investigated the area of educators' digital competence training that presented the training needs [80-82]. However, for students, there is a relationship between training and their subsequent development of digital competence [3].

\section{Conclusions}

This paper explores the perceived digital competence of a sample of university students at a university in north western China. Positive aspects of information and data literacy, communication and collaboration, security and problem solving were noted, while digital content creation was also shown to be the dimension of least awareness among the students. In addition to this, the impact of personal variables on perceptions of digital competence were examined, pointing to gender gaps, grade differences, urban-rural area differences, and the impact of prior formal training on digital competence.

The emergence of the epidemic has led to a faster and deeper penetration of multimedia technology into the education sector, making it important to understand where students' digital competence levels are at. In this paper, the results obtained not only show the students' current perceived level of digital competence, but also provide a perception of the digital competence of students in different education systems for later comparison with students in other countries or in other educational contexts. It also contributes reference data for teachers and educational institutions in developing relevant training and education strategies.

This study is not without its limitations. First, the sample was from students at the same university. Future research is recommended to expand sample diversity. Moreover, the study was based on a self-perception questionnaire rather than an objective assessment of digital competence. That is, the self-statements were subjective and therefore may not reflect the true current level of students' digital competence. It is suggested that future studies applying correlation and regression analyses to allow further exploration of the effects of the variables on digital competence and how the components of digital competence are interrelated.

Author Contributions: Conceptualization, Y.Z., M.C.S.G. and A.M.P.L.; methodology, Y.Z., M.C.S.G. and A.M.P.L.; software, Y.Z.; validation, all authors; formal analysis, Y.Z.; resources, L.Z.; data curation, Y.Z.; writing - original draft preparation, Y.Z.; writing-review and editing, M.C.S.G., A.M.P.L. and L.Z.; visualization, Y.Z.; supervision, M.C.S.G., A.M.P.L. and L.Z. All authors have read and agreed to the published version of the manuscript.

Funding: This research received no external funding.

Institutional Review Board Statement: Not applicable.

Informed Consent Statement: Informed consent was obtained from all subjects involved in the study.

Data Availability Statement: Not applicable.

Conflicts of Interest: The authors declare no conflict of interest.

\section{References}

1. Schleicher, A. The Impact of COVID-19 on Education Insights from Education at a Glance 2020. Available online: https://www. oecd.org/education/the-impact-of-covid-19-on-education-insights-education-at-a-glance-2020.pdf (accessed on 7 August 2021).

2. Portillo, J.; Garay, U.; Tejada, E.; Bilbao, N. Self-Perception of the Digital Competence of Educators during the COVID-19 Pandemic: A Cross-Analysis of Different Educational Stages. Sustainability 2020, 12, 10128. [CrossRef]

3. Sánchez-Caballé, A.; Gisbert Cervera, M.; Esteve-Mon, F.M. The digital competence of university students: A systematic literature review. Aloma 2020, 38, 63-74. [CrossRef]

4. Zhao, Y.; Pinto Llorente, A.M.; Sánchez Gómez, M.C.; Zhao, L. The Impact of Gender and Years of Teaching Experience on College Teachers' Digital Competence: An Empirical Study on Teachers in Gansu Agricultural University. Sustainability 2021, $13,4163$. [CrossRef]

5. European Union. Digital Education Action Plan. 2020. Available online: https://ec.europa.eu/education/education-in-the-eu/ digital-education-action-plan_en (accessed on 28 July 2021). 
6. Gobierno de España. Plan de España Digital 2025. 2020. Available online: https://portal.mineco.gob.es/en-us/ministerio/ estrategias/Pages/00_Espana_Digital_2025.aspx (accessed on 2 August 2021).

7. China Internet Network Information Center. The 48th China Statistical Report on Internet Development. 2021. Available online: http:/ /n2.sinaimg.cn/finance/a2d36afe/20210827/FuJian1.pdf (accessed on 1 September 2021).

8. Cyberspace Administration of China. Digital China Development Report 2020. 2020. Available online: http://www.cac.gov.cn/ 2021-06/28/C_1626464503226700.htm (accessed on 4 September 2021).

9. Radovanović, D.; Hogan, B.; Lalić, D. Overcoming digital divides in higher education: Digital literacy beyond Facebook. New Media Soc. 2015, 17, 1733-1749. [CrossRef]

10. Groves, M.; Sellars, C.; Smith, J.; Barber, A. Factors Affecting Student Engagement: A Case Study Examining Two Cohorts of Students Attending a Post-1992 University in the United Kingdom. Int. J. High. Educ. 2015, 4, 27-37. [CrossRef]

11. Bergdahl, N.; Nouri, J.; Fors, U. Disengagement, engagement and digital skills in technology-enhanced learning. Educ. Inf. Technol. 2020, 25, 957-983. [CrossRef]

12. Heidari, E.; Mehrvarz, M.; Marzooghi, R.; Stoyanov, S. The role of digital informal learning in the relationship between students' digital competence and academic engagement during the COVID-19 pandemic. J. Comput. Assist. Learn. 2021, 37, 1154-1166. [CrossRef] [PubMed]

13. Carretero Gomez, S.; Vuorikari, R.; Punie, Y. DigComp 2.1: The Digital Competence Framework for Citizens with Eight Proficiency Levels and Examples of Use, EUR 28558 EN; Publications Office of the European Union: Luxembourg, 2017; Available online: https:/ / ec.europa.eu/jrc/en/publication/eur-scientific-and-technical-research-reports/digcomp-21-digital-competenceframework-citizens-eight-proficiency-levels-and-examples-use (accessed on 20 July 2021).

14. Gómez-Fernández, N.; Mediavilla, M. Exploring the relationship between Information and Communication Technologies (ICT) and academic performance: A multilevel analysis for Spain. Socio-Econ. Plan. Sci. 2021, 77, 101009. [CrossRef]

15. Gudmundsdottir, G.B.; Hernandez Gasso, H.; Colomer Rubio, J.C.; Hatlevik, O.E. Student teachers' responsible use of ICT: Examining two samples in Spain and Norway. Comput. Educ. 2020, 152, 103877. [CrossRef]

16. Ferrari, A. Digital Competence in Practice: An Analysis of Frameworks. 2012. Available online: https://pdfs.semanticscholar. org/851f/ebe72df176a16ad6e26b00ff5df35520da34.pdf (accessed on 8 August 2021).

17. European Commission. Key Competences for Lifelong Learning. 2019. Available online: https://op.europa.eu/en/publicationdetail/- / publication/297a33c8-a1f3-11e9-9d01-01aa75ed71a1/language-en/format-PDF/source-231945798 (accessed on 10 August 2021).

18. Janssen, J.; Stoyanov, S.; Ferrari, A.; Punie, Y.; Pannekeet, K.; Sloep, P. Experts' views on digital competence: Commonalities and differences. Comput. Educ. 2013, 68, 473-481. [CrossRef]

19. OECD. The OECD Program Definition and Selection of Competencies. The Definition and Selection of Key Competencies. Executive Summary, 2005. Available online: http:/ / www.oecd.org/dataoecd/47/61/35070367.pdf (accessed on 11 August 2021).

20. Calvani, A.; Cartelli, A.; Fini, A.; Ranieri, M. Models and instruments for assessing digital competence at school. J. E-Learn. Knowl. Soc. Version 2009, 4, 183-193.

21. Calvani, A.; Fini, A.; Ranieri, M.; Picci, P. Are young generations in secondary school digitally competent? A study on Italian teenagers. Comput. Educ. 2012, 58, 797-807. [CrossRef]

22. From, J. Pedagogical Digital Competence-Between Values, Knowledge and Skills. High. Educ. Stud. 2017, 7, 43-50. [CrossRef]

23. Altuna Urdín, J.; Martínez de Morentin de Goñi y Amenabar Perurena, N. Las teorías de enseñanza-aprendizaje y los recursos de Internet: Su confluencia en centros de primaria. Estud. Sobre Educ. 2017, 33, 145-167. [CrossRef]

24. Kampylis, P.; Punie, Y.; Devine, J. European Framework for Digitally Competent Educational Organisations. 2016. Available online: https:/ / ec.europa.eu/jrc/en/digcomporg (accessed on 14 August 2021).

25. Krumsvik, R.J. Skulen og den Digitale Læringsrevolusjonen; Universitetsforlaget: Oslo, Norway, 2007.

26. Redecker, C. European Framework for the Digital Competence of Educators: DigCompEdu (No. JRC107466); Joint Research Centre: Seville, Spain, 2017.

27. Prensky, M. How to teach with technology: Keeping both teachers and students comfortable in an era of exponential change. Emerg. Technol. Learn. 2007, 2, 40-46.

28. Eger, L.; Klement, M.; Tomczyk, L.; Pisonova, M.; Petrova, G. Different user groups of university students and their ict competence: Evidence from three countries in central europe. J. Balt. Sci. Educ. 2018, 17, 851-866. [CrossRef]

29. Kwon, D. Digital Competence of Students with Disabilities Using a Mobile Device in a Post-Secondary Transition Program for Potential Employment. Ph.D. Thesis, The University of Alabama, Tuscaloosa, AL, USA, 2021. Available online: https: / /ir.ua.edu/handle/123456789/7944 (accessed on 11 August 2021).

30. Toquero, C.M. Challenges and opportunities for higher education amid the COVID-19 pandemic: The Philippine context. Pedagog. Res. 2020, 5, em0063. [CrossRef]

31. Cabezas, M.; Casillas, S. Are Future Social Educators Digital Residents? Rev. Electron. Investig. Educ. 2017, 19, 61-72.

32. Liesa-Orús, M.; Vázquez-Toledo, S.; Lloret-Gazo, J. Identificación de las fortalezas y debilidades de la competencia digital en el uso de aplicaciones de internet del alumno de primer curso del Grado de Magisterio. Rev. Complut. Educ. 2016, 27, 845-862. [CrossRef]

33. Rodríguez, M.D.M.; Méndez, V.G.; Martín, A.M.R.M.R. Alfabetización informacional y competencia digital en estudiantes de magisterio. Profr. Rev. Currículum Y Form. Del Profr. 2018, 22, 253-270. [CrossRef] 
34. López-Meneses, E.; Sirignano, F.M.; Vázquez-Cano, E.; Ramírez-Hurtado, J.M. University students' digital competence in three areas of the DigCom 2.1 model: A comparative study at three European universities. Australas. J. Educ. Technol. 2020, 36, 69-88. [CrossRef]

35. The General Office of the CPC Central Committee and the General Office of the State Council. China Education Modernization 2035, China State Council Website. 2017. Available online: http://www.gov.cn/zhengce/2019-02/23/content_5367987.html (accessed on 7 August 2021).

36. Ministry of Education of China. Education Informatization 2.0 Action Plan, Ministry of Education of China Website. 2018. Available online: http://www.moe.gov.cn/srcsite/A16/s3342/201804/t20180425_334188.html (accessed on 18 August 2021).

37. Agreda Montoro, M.; Hinojo Lucena, M.A.; Sola Reche, J.M. Design and validation of an instrument for assess digital skills of teachers in Spanish higher education. Pixel-Bit-Rev. Medios Y Educ. 2016, 49, 39-56. [CrossRef]

38. Benali, M.; Kaddouri, M.; Azzimani, T. Digital competence of Moroccan teachers of English. Int. J. Educ. Dev. Using ICT 2018, 14, 99-120.

39. Hinojo-Lucena, F.J.; Aznar-Diaz, I.; Cáceres-Reche, M.P.; Trujillo-Torres, J.M.; Romero-Rodriguez, J.M. Factors influencing the development of digital competence in teachers: Analysis of the teaching staff of permanent education centres. IEEE Access 2019, 7, 178744-178752. [CrossRef]

40. Guillén-Gámez, F.D.; Mayorga-Fernández, M.J.; Bravo-Agapito, J.; Escribano-Ortiz, D. Analysis of teachers' pedagogical digital competence: Identification of factors predicting their acquisition. Technol. Knowl. Learn. 2020, 26, 481-498. [CrossRef]

41. Soroko, N. Methodology for Teachers' Digital Competence Developing through the Use of the STEAM-oriented Learning Environment. In ICTERI Workshops; DBIP: Kharkiv, Ukraine, 2020; pp. 1260-1271.

42. Lucas, M.; Bem-Haja, P.; Siddiq, F.; Moreira, A.; Redecker, C. The relation between in-service teachers' digital competence and personal and contextual factors: What matters most? Comput. Educ. 2021, 160, 104052. [CrossRef]

43. Ministration of Education of China. Number of Students of Formal Education by Type and Level. Available online: http: //www.moe.gov.cn/s78/A03/moe_560/jytjsj_2019/qg/202006/t20200611_464803.html (accessed on 21 August 2021).

44. Zhao, Y.; Llorente, A.M.P.; Gómez, M.C.S. Digital competence in higher education research: A systematic literature review. Comput. Educ. 2021, 168, 104212. [CrossRef]

45. Vuorikari, R.; Punie, Y.; Gomez, S.C.; Van Den Brande, G. DigComp 2.0: The Digital Competence Framework for Citizens. Update Phase 1: The Conceptual Reference Model (No. JRC101254); Joint Research Centre: Seville, Spain, 2016.

46. European Commission. Recommendation of the European Parliament and of the council of 18 December 2006 on key competences for lifelong learning. Off. J. Eur. Union 2006, 394, 10-18.

47. Kluzer, S.; Rissola, G. Guidelines on the Adoption of DigComp; Telecenter Europe. 2015. Available online: https://all-digital. org/resources/guidelines-adoption-digcomp/ (accessed on 23 August 2021).

48. Sánchez-Cruzado, C.; Santiago Campión, R.; Sánchez-Compaña, M.T. Teacher Digital Literacy: The Indisputable Challenge after COVID-19. Sustainability 2021, 13, 1858. [CrossRef]

49. Feijóo, C.; Fernández, J.; Arenal, A.; Armuña, C.; Ramos, S.; Punie, Y.; Vuorikari, R. Educational Technologies in China. 2021. Available online: https:/ / publications.jrc.ec.europa.eu/repository/handle/JRC124648 (accessed on 24 August 2021).

50. Hernandez, R.; Fernandez, C.; Baptista, P. Metodología de la Investigacion; McGraw Hill: Santa Fe, Mexico, 2014.

51. Martínez, J.G.; Vidal, C.E.; Cervera, M.G. La evaluación cero de la competencia nuclear digital en los nuevos grados del EEES. @ tic. Rev. D'innovació Educ. 2010, 4, 13-20.

52. Kluzer, S.; Priego, L.P. Digcomp into Action: Get Inspired, Make It Happen. A User Guide to the European Digital Competence Framework (No. JRC110624); Joint Research Centre: Seville, Spain, 2018.

53. Bisquerra, R. Metodología de la Investigación Educativa, 2nd ed.; La Muralla: Madrid, Spain, 2016.

54. Guillén-Gámez, F.D.; Mayorga-Fernández, M.J.; Álvarez-García, F.J. A study on the actual use of digital competence in the practicum of education degree. Technol. Knowl. Learn. 2020, 25, 667-684. [CrossRef]

55. Cabezas-González, M.; Casillas-Martín, S.; García-Peñalvo, F.J. The Digital Competence of Pre-Service Educators: The Influence of Personal Variables. Sustainability 2021, 13, 2318. [CrossRef]

56. Pérez-Navío, E.; Ocaña-Moral, M.T.; Martínez-Serrano, M.d.C. University Graduate Students and Digital Competence: Are Future Secondary School Teachers Digitally Competent? Sustainability 2021, 13, 8519. [CrossRef]

57. Porln, I.G.; Snchez, J.S. Evaluation and development of digital competence in future primary school teachers at the University of Murcia. J. New Approaches Educ. Res. (NAERJ.) 2016, 5, 51-56.

58. Cabezas González, M.; Casillas Martín, S.; Sanches-Ferreira, M.; Teixeira Diogo, F.L. Do gender and age affect the level of digital competence? A study with university students. Fonseca-J. Commun. 2017, 15, 115-132.

59. Llorent-Vaquero, M.; Tall'on-Rosales, S.; de las Heras Monastero, B. Use of information and communication technologies (ICTs) in communication and collaboration: A comparative study between university students from Spain and Italy. Sustainability 2020, 12, 3969. [CrossRef]

60. Martzoukou, K.; Fulton, C.; Kostagiolas, P.; Lavranos, C. A study of higher education students' self-perceived digital competences for learning and everyday life online participation. J. Doc. 2020, 76, 1413-1458. [CrossRef]

61. Gallego-Arrufat, M.J.G.A.; Torres-Hernández, N.T.H.; Pessoa, T.P.; Gallego-Arrufat, M.J.; Torres-Hernández, N.; Pessoa, T. Competence of future teachers in the digital security area. Comun. Media Educ. Res. J. 2019, 27, 57-67. [CrossRef] 
62. García-Holgado, A.; Verdugo-Castro, S.; Sánchez-Gómez, M.C.; García-Peñalvo, F.J. Trends in studies developed in Europe focused on the gender gap in STEM. In Proceedings of the XX International Conference on Human Computer Interaction, Gipuzkoa, Spain, 25-28 June 2019; pp. 1-8.

63. Cózar, R.; Roblizo, M.J. La competencia digital en la formación de los futuros maestros: Percepciones de los alumnos de los Grados de Maestro de la Facultad de Educación de Albacete. RELATEC Rev. Latinoam. Tecnol. Educ. 2014, 13, 119-133.

64. Basantes-Andrade, A.; Cabezas-González, M.; Casillas-Martín, S. Digital competences relationship between gender and generation of university professors. Int. J. Adv. Sci. Eng. Inf. Technol. 2020, 1, 205-2011. [CrossRef]

65. Rodríguez-Muñiz, L.J.; Burón, D.; Aguilar-González, Á.; Muñiz-Rodríguez, L. Secondary Mathematics Teachers' Perception of Their Readiness for Emergency Remote Teaching during the COVID-19 Pandemic: A Case Study. Educ. Sci. 2021, 11, 228. [CrossRef]

66. Gil-Juarez, A.; Vitores, A.; Feliu, J.; Vall-Llovera, M. Digital Gender Gap: A Review and a Proposal. EKS 2011, 12, 25-53. [CrossRef]

67. Guillén-Gámez, F.D.; Perrino, M. Análisis Univariante de la Competencia Digital en Educación Física: Un estudio empírico. Retos 2020, 37, 326-332.

68. Ruíz-Cabezas, A.; Medina, M.C.; Pérez, E. University teachers' ${ }^{\prime}$ training: The Digital Competence. Pixel-Bit 2020, 58, 181-215. [CrossRef]

69. Sanchez Prieto, J.; Trujillo Torres, J.M.; Gomez Garcia, M.; Gomez Garcoa, G. Gender and digital teaching competence in dual vocational education and training. Educ. Sci. 2020, 10, 84. [CrossRef]

70. Galindo-Domínguez, H.; Bezanilla, M.J. Digital competence in the training of pre-service teachers: Perceptions of students in the degrees of early childhood education and primary education. J. Digit. Learn. Teach. Educ. 2021, 1-16.

71. Lopez, J.; Pozo, S.; Fuentes, A. Analysis of electronic leadership and digital competence of teachers of educational cooperatives in Andalucia (Spain). Multidiscip. J. Educ. Res. 2019, 9, 194-223. [CrossRef]

72. Jiménez-Hernández, D.; González-Calatayud, V.; Torres-Soto, A.; Martínez Mayoral, A.; Morales, J. Digital Competence of Future Secondary School Teachers: Differences According to Gender, Age, and Branch of Knowledge. Sustainability 2020, $12,9473$. [CrossRef]

73. Moreno-Guerrero, A.J.; Fernandez Mora, M.A.; Alonso Garcia, S. Inflfluencia del genero en la competencia digital docente. Rev. Espac. 2019, 40, 30.

74. Pérez-Escoda, A.; Castro-Zubizarreta, A.; Fandos-Igado, M. Digital Skills in the Z Generation: Key Questions for a Curricular Introduction in Primary Schoolq. Comun. Media Educ. Res. J. 2016, 24, 71-79. [CrossRef]

75. Feldmann, J.; Khodabakhsh, P.; Valiucko, D.; Weber, C.; Beck, C. Study on National Broadband Plans in the EU-28; Publications Office of the EU: Luxembourg, 2014.

76. Blank, G.; Graham, M.; Calvino, C. Local Geographies of Digital Inequality. Soc. Sci. Comput. Rev. 2018, 36, 82-102. [CrossRef]

77. Rundel, C.; Salemink, K. Bridging Digital Inequalities in Rural Schools in Germany: A Geographical Lottery? Educ. Sci. 2021, 11, 181. [CrossRef]

78. Girón, V.; Cózar-Gutiérrez, R.; González-Calero, J.A. Análisis de la autopercepción sobre el nivel de competencia digital docente en la formación inicial de maestros/as. Rev. Electrónica Interuniv. Form. Del Profr. 2019, 22, 193-218.

79. Romero-Tena, R.; Barragán-Sánchez, R.; Llorente-Cejudo, C.; Palacios-Rodríguez, A. The Challenge of Initial Training for Early Childhood Teachers. A Cross Sectional Study of Their Digital Competences. Sustainability 2020, 12, 4782. [CrossRef]

80. Sur, E.; Ünal, E.; Iseries, K. Primary School second grade teachers' and students' opinions on media literacy. Comun. Media Educ. Res. J. 2014, 22, 119-127. [CrossRef]

81. Cabezas, M.; Casillas, S.; Pinto, A.M. Percepción de los alumnos de Educación Primaria de la Universidad de Salamanca sobre su competencia digital. EDUTEC Rev. Electrónica Tecnol. Educ. 2014, 48, a275.

82. Sánchez, S.P.; Belmonte, J.L.; Cruz, M.F.; Antonio, J. Análisis correlacional de los factores incidentes en el nivel de competencia digital del profesorado. Rev. Electrónica Interuniv. Form. Del Profr. 2020, 23, 143-159. [CrossRef] 